11. Strang A. J. Fatigue-induced early onset of anticipatory postural adjustments in non-fatigued muscles: support for a centrally mediated adaptation / A. J. Strang, W. P. Berg, M. Hieronymus // Exp. Brain Res. - 2009. - Vol. 197, № 3. P. 245-254.

12. Chang W. H. Role of the premotor cortex in leg selection and anticipatory postural adjustments associated with a rapid stepping task in patients with stroke / W. H. Chang, P. F. Tang, Y. H. Wang [et al.] // Gait Posture. - 2010. Vol. 32, № 4. - P. 487-493.

13. Silva A. Activation timing of soleus and tibialis anterior muscles during sit-to-stand and stand-to-sit in poststroke vs. healthy subjects / A. Silva, A. S. Sousa, R. Pinheiro [et al.] // Somatosens Mot. Res. - 2013. - Vol. 30, № $1 .-$ P.48-55.

14. Rogers M. W. Postural preparation prior to stepping in patients with Parkinson's disease / M. W. Rogers, R. Kennedy, S. Palmer [et al.] // J. Neurophysiol. - 2011. - Vol. 106, № 2. - P. 915-924.

Іванченко Олена. Випереджальні зміни тонічної ЕМГ-активності камбалоподібного м'яза при довільних рухах контралатерального гомілковостопного суглоба. У здорових людей вивчали зміни тонічної ЕМГактивності камбалоподібного м'яза в преморному періоді довільних рухів контралатеральної нижньої кінцівки в гомілковостопному суглобі. Показано, що при вертикальному положенні обстежених характер змін тонічної ЕМГ-активності визначався видом руху: при розгинанні гомілковостопного суглоба спостерігали зменшення іiі інтенсивності, а при згинанні - збільшення. Указані явища проявлялись уже за 90 мс до початку обох видів рухів і тривали протягом усього їх премоторного періоду. При положенні обстежених лежачи тонічна ЕМГактивність камбалоподібного м'яза в умовах згинання й розгинання контралатерального гомілковостопного суглоба не змінювалась. Результати дослідження свідчать, що зміни тонічної ЕМГ камбалоподібного м'яза, які виникають перед початком довільних рухів контралатеральної кінцівки тільки при вертикальному положенні обстежених, слугують проявом випереджальних постуральних перебудов, що сприяють адекватному виконанню антигравітаційної функції рухового апарату людини.

Ключові слова: тонічна ЕМГ-активність, камбалоподібний м'яз, довільні рухи, контралатеральна кінцівка, гомілковостопний суглоб, премоторний період, випереджальні постуральні перебудови.

Ivanchenko Elena. Anticipatory Changes of the Tonic EMG-activity Soleus Muscle During Voluntary Movements of Contralateral Ankle Joint. In healthy humans we studied changes of the tonic EMG-activity m.soleus before beginning of voluntary movements of the contralateral lower limb in ankle joint. It is shown that during standing position of people the nature of these changes depended on type of movement: extension and flexion of ankle joint caused decrease and increase of EMG intensity respectively. These phenomena manifistated behind $90 \mathrm{~ms}$ to both kinds of movements and continued throughout all premotor period. In lying position of people the tonic EMG activity m.soleus did not change before flexion and extension contralateral ankle. Results of the study suggest that changes m.soleus tonic EMG arising before voluntary movements contralateral limb only at human vertical pose, are the manifestation of anticipatory postural alterations that contribute to the implementation of adequate antigravity function of the motor system of man.

Key words: tonic EMG-activity, m. soleus, voluntary movements, contralateral limb, ankle joint, premotor period, anticipatory postural adjustments.

Статья поступила в редколлегию 08.03.2016 г.

УДК: 577.3

Яків Фіщенко, Данило Заводовський, Олександр Мотузюк, Тетяна Матвіснко, Дмитро Ноздренко, Вікторія Мельничук, Ольга Дубнік

\title{
Вплив лонгідази на індукований епідуральний фіброз спинного мозку
}

Досліджено вплив лонгідази в дозі 1мл/кг на індукований епідуральний фіброз спинного мозку щура. Показано зниження кількості фіброзних структур при застосуванні препарату. При цьому співвідношення

(C) Фіщенкко Я., Заводовський Д., Мотузюк О., Матвієнко Т., Ноздренко Д., Мельничук В., Дубнік О., 2016 
кількості сполучної тканини в різні періоди після ініціації фіброзу зменшилося на 23 \% після п’ятої доби експерименту й на 38 \% - після 10. Зменшення максимальної товщини фіброзу становило, відповідно, 31 та 43 \%. Найсуттєвіші зміни проявились у зменшенні загальної площі фіброзного утворення - на 46 \% після п'ятої доби експерименту й $68 \%$ - після 10. Результати засвідчили, що лонгідаза може знижувати епідуральну рубцеву адгезію в піддослідних щурів і чинить позитивну дію на запобігання епідуральному фіброзу й забезпечує зменшення щільності фіброзної тканини.

Ключові слова: фіброз, сполучна тканина, лонгідаза.

Постановка наукової проблеми та ії значення. Однією з головних та найскладніших проблем сучасної вертебрології є післяопераційний епідуральний фіброз (ПОЕФ). Він виникає внаслідок післяопераційного втручання, пов'язаного з остеохондрозом. ПОЕФ викликає сильні хронічні болі, має негативний вплив на післяопераційне відновлення пацієнта та значно знижує результат операції видалення грижі [1]. Фіброз - це розростання сполучної тканини внаслідок певного діючого фактора, що супроводжується рубцюванням. Фіброз може утворюватись у різних тканинах й органах. Так, наприклад, виділяють фіброз печінки, сечового міхура та ін. До факторів, що викликають фіброзні хвороби, відносять травми, опромінення, хірургічне втручання, алергію, інфекції й ін. [2].

На молекулярному рівні фіброз тканин можна розглядати як певний збій у процесі загоєння ран. За нормальних умов на місці травми повинна утворитися сполучна тканина. Для цього процесу мезенхімальні фібробласти активуються, починають проліферувати й мігрують у рану, де починають синтезувати у великих кількостях білки матриксу - колаген та фібронектин. Фібробласти, присутні в рані - міофібробласти, - синтезують $\alpha$-SMA-фактор (фактор росту для $\alpha$-актоміозину), який є обов'язковим для закриття, рубцювання ран [3, 4]. Імовірно, на певній стадії цього циклу відбувається збій, але сам механізм утворення фіброзу ще не достатньо вивчений. На тканинному рівні фіброз являє собою сполучну тканину 3 рубцюванням, що огортається навколо нервового корінця й починає стискувати його та, можливо, судини, що містяться поряд. Це призводить до больового синдрому.

Відомо, що фіброз розвивається за 3-12 тижнів [5]. Неврологічна картина ПОЕФ являє собою ішемічні ураження каудальних відділів спинного мозку [6]. Ортопедичні зміни у хворих не є дуже помітними. Вони виражаються в згладженості поперекового лордозу, зміні постави, ходьби, обмеженні рухливості попереково-крижового відділу хребта. На жаль, поки що не існує ефективного лікування фіброзних хвороб. До терапевтичних методів лікування фіброзів можна віднести протибольову терапію, використання засобів, що покращують мікроциркуляцію, засобів проти набряку, фізіотерапію та гіперболічну оксигенацію. До медикаментозних засобів лікування хронічного болю при фіброзах належать лікування анестетиками, протизапальними, десенсибілізаційними, протинабряковими препаратами. Метод, який використовують для вводу ліків при гострих больових синдромах, називається епідуральною блокадою. За ним ліки вводять між твердою мозковою оболонкою й внутрішнім краєм міжхребцевого отвору. Стандартно використовують місцеві анестетики, нерідко у комплексі з глюкокортикоїдами $[7,8,9]$.

До сьогодні не існує ефективного лікування ПОЕФ, що є великою проблемою для сучасної медицини. Саме тому ця тема актуальна та важлива для подальшого вивчення У деяких випадках як один із компонентів лікування застосовують препарат лонгідазу, діюча речовина якої - суміш гіалуронідази та броміду азоксимеру. За фрамокологічною дією препарат відносять до ферментів. Лонгідаза має ферментативну, імуносупресорну, хілатуючу активність, антиоксидантні та протизапальні властивості. Гіалуронідаза гідролізує глікозаміноглікани: гіалуронову кислоту, хондроитин, хондроитин-4-сульфат, хондроитин-6-сульфат. Результатом такого гідролізу $\epsilon$ тетрасахариди. Унаслідок гідролізу зменшується активність глікозаміногліканів, здатність зв'язувати воду та іони металів останніх. Через це збільшується проникність тканин, покращуються їхні трофічні властивості, зменшуються набряки, зникають гематоми, збільшується еластичність ділянок із рубцями [10]. Бромід азоксимеру, котрий входить до складу препарату, має яскраво вираженні імуностимуляційні та дезінтоксикаційні властивості [11]. Найкращий ефект спостерігають при використанні цього препарату на ранніх стадіях патологічних процесів. Усе це дає перспективу для вивчення впливу препарату на індукований епідуральний фіброз спинного мозку.

Методи дослідження. Дослідження проводили на 16 дорослих щурах масою від 0,2 до 0,3 кг, яких поділено на дві групи: контрольну (вісім тварини) і дослідну (вісім тварин). За тривалістю часу після активації розвитку фіброзу групи розділено на дві підгрупи (по чотири особини в кожній): I - 
час після активації фіброзу складав п’ять діб, II - 10 діб. При попередній підготовці до експерименту анестезію здійснювали внутрішньочеревним уведенням нембуталу (40 мг/кг). Фіброз викликали хірургічним методом, через пошкодження твердої мозкової оболонки поперекових відділів хребта наркотизованих щурів, методом розривів волокон межхребцевих дисків. В епідуральну порожнину піддослідних тварин уводили препарат лонгідази в концентраціях 1мл на 1кг ваги тварини. Після п'яти та 10 діб після ініціації фіброзу тварин забивали методом декапітації й виділяли спинний мозок. Його спинний мозок фіксували протягом двох тижнів у 10 \% формаліні, після чого - протягом 10 днів у 7 \% формаліні. Фіксований матеріал промивали під струменем проточної води протягом однієї доби для звільнення від фіксатора. Потім матеріал зневоднювали. Для цього використовували спирти зростаючих концентрацій: 60 \% спирт - шість годин, 70 \% - шість годин, 80 \% - шість годин, $90 \%$ - чотири години, $100 \%$ - дві години. Зазвичай, матеріал перебував у спирті не менше 24 годин, оскільки повне зневоднювання - найважливіша умова успішної заливки.

Для приготування зрізів заливали матеріал у парафін-воскову суміш (95\% парафіну й 5 \% очищеного воску). Перед цим його поміщали в суміш різних частин абсолютного спирту й ксилолу на 1 год. Потім переносили матеріал в ортоксилол на 30-40 хв. Після цього поміщали в насичений розчин парафіну в ортоксилолі при $37^{\circ} \mathrm{C}$ на одну годину, переносили в перший чистий парафін до 2 год при $57^{\circ} \mathrm{C}$, а потім - у другий чистий парафін до 1 год при $57^{\circ} \mathrm{C}$. Заливали матеріал чистим парафіном у формочки 3 паперу, охолоджували у воді та вирізали блок, який наклеювали розплавленим парафіном на дерев'яний кубик.

Різку блоків проводили серійно, паралельно й перпендикулярно до ходу м'язових волокон на санному мікротомі (MC-2) товщиною 10 мкм. Виявлення сполучної тканини проводили за класичним методом зафарбовування за Ван-Гізон [12].

Фотографування гістологічних препаратів здійснювали за допомогою цифрової камери SEO на мікроскопі Axioscop фірми «Carl ZEISS». Обробку цифрових фотографій форматів JPEG проводили в програмі Adobe Photoshop 8.0. Фотографії, отримані за допомогою світлової електронної мікроскопії оброблялися за допомогою програми «ВідеоТест Морфологія 5.0» При обробці отриманих цифрових даних використовували методи варіаційної статистики. Достовірність відмінностей між групами визначали за t-критерієм Стьюдента.

Виклад основного матеріалу й обгрунтування отриманих результатів дослідження. Механізми надлишкового формування сполучної тканини в епідуральному просторі у відповідь на операційну травму до кінця ще не вивчені. Однак збільшення сполучнотканинних компонентів та формування фіброзу навколо твердої мозкової оболонки є незаперечним. Передусім, в оболонці починає швидко змінюватися співвідношення скоротливих елементів до сполучнотканинних, у бік збільшення останніх зі збільшенням часу після індукції фіброзу (рис.1). Формування фіброзу довкола твердої мозкової оболонки, з одного боку, призводить до стискування нервових корінців, а з іншого - може збільшити ризик специфічних ускладнень при спинальному повторному втручанні (гематом i порушень твердих мозкових оболонок). Гіперплазія, або патологічне зростання сполучної тканини, найчастіше $\epsilon$ наслідком продуктивної фази хронічного запалення, викликаного як інфекційними, так i хірургічними чинниками. Запалення викликає зростання кількості сполучної тканини. Ключовим моментом продуктивної фази процесу запалення й формування фіброзу є стимуляція функції фібробластів як макрофагіальними цитокінами, так і продуктами деструкції сполучної тканини.

Товщина прошарку сполучної тканини на 10 добу після активації фіброзу зросла у 7,5 раза, порівняно з нормою, та в 1,3 раза, порівняно з п’ятою добою після ініціації фіброзу (рис. 2). Значно збільшилось і співвідношення кількості сполучної тканини в різні періоди після ініціації фіброзу (рис. 3,4$)$. Загальна площа фіброзних утворювань між 5-ю та 10 добами зросла в 1,8 раза (рис. 4). Отже, у цьому випадку маємо стрімке зростання прошарку колагенових волокон зі збільшенням часу після виникнення (ПОЕФ). Імовірно, що зміни зачепили внутрішні компоненти жорсткості, які в клітині представлені цитоскелетом, що дало позитивну динаміку розростанню сполучної тканини 3 появою рубцевих змін, які виникають, зазвичай, у результаті хронічного запалення. 

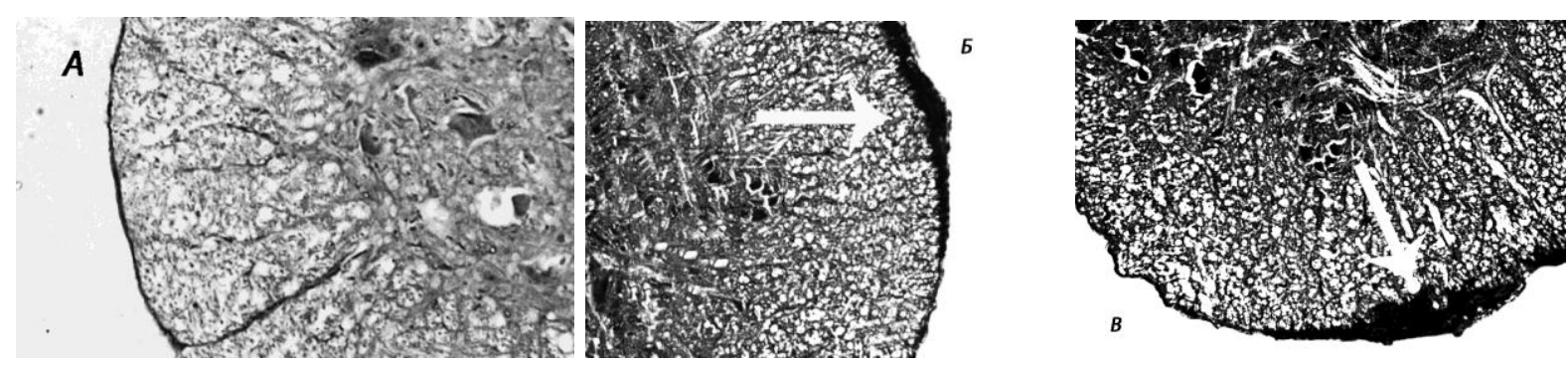

Рис. 1. Поперечний переріз нативного спинного мозку щура (а), 5 (б) та 10 (в) діб після активації фіброзу (світлова мікроскопія, х100)

Стрілками показано місця виникнення фіброзних структур.

Після введення препарату лонгідази в концентрації 1мл/кг кількість фіброзних утворень у досліджуваних препаратах значно зменшилася (рис. 3, 4, 5) Це стосується всіх фіксованих параметрів. Співвідношення кількості сполучної тканини в різні періоди після ініціації фіброзу зменшилася на $23 \%$ після п'ятої доби експерименту й на 38 \% після 10 діб. Зменшення максимальної товщини фіброзу склало, відповідно, 31 та 43 \%. Найсуттєвіші зміни проявились у зменшенні загальної прощі фіброзного утворення на 46 \% після п'ятої доби експерименту й 68 \% - після 10 діб (рис. 5).

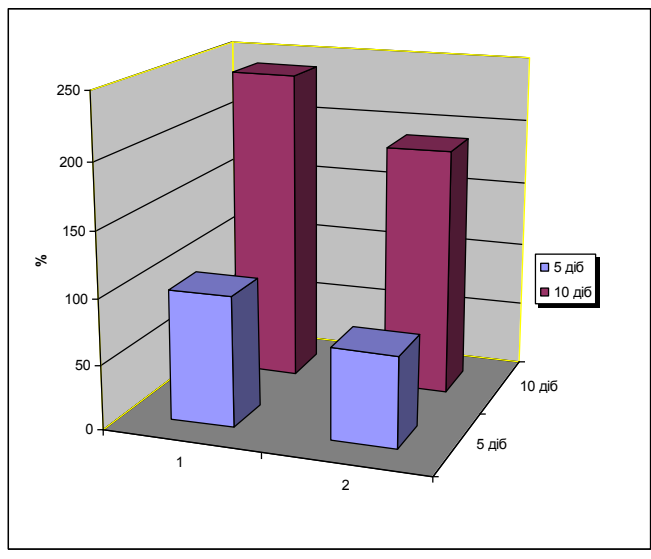

Рис 2. Співвідношення кількості сполучної тканини в різні періоди після ініціації фіброзу, у відсотках від контрольних значень:

1-5 та 10 діб після активації фіброзу;

2-5 та 10 діб після активації фіброзу при введені препарату лонгідази в концентрації 1мг/кг.

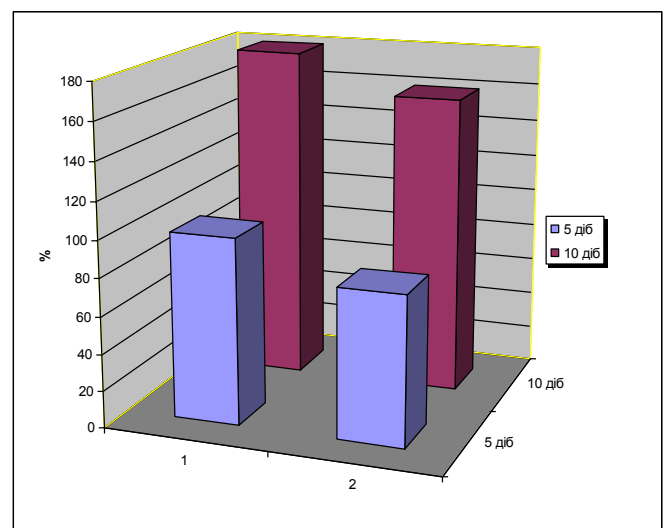

Рис. 3. Максимальна товщчина прошарку сполучної тканини в різні періоди після ініціації фіброзу, у відсотках від контрольних значень:

А - 5 та 10 діб після активації фіброзу

Б - 5 та 10 діб після активації фіброзу при введені препарату лонгідази в концентрації 1 мг/кг.

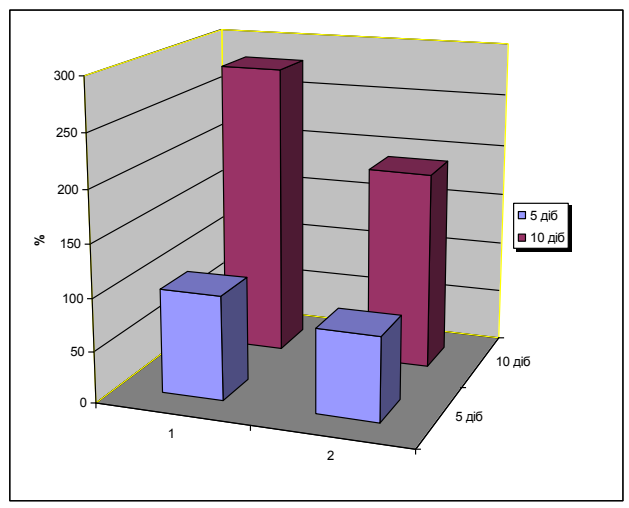

Рис. 4. Загальна площуа фіброзного утворення в різні періоди після ініціації фіброзу, у відсотках від контрольних значень:

А - 5 та 10 діб після активації фіброзу;

Б - 5 та 10 діб після активації фіброзу при введені препарату лонгідази в концентрації 1 мг/кг. 
Значно вищий клінічний ефект препарату лонгідази, ніж ефект нативної гіалуронідази [7], можна пояснити тим, він являє собою кон'югат протеолітичного ферменту гіалуронідази з високомолекулярним носієм із групи похідних n-оксиду поли-1,4-етиленпиперазину. Кон'югація підвищує стійкість ферменту до дії температури й інгібіторів, збільшує його активність і приводить до пролонгації дії. Також ферментативна активність лонгідази зберігається при нагріванні до $37^{\circ} \mathrm{C}$ протягом 20 діб, тоді як нативна гіалуронідаза в цих же умовах утрачає свою активність протягом доби [9]. Ковалентний зв'язок лонгідази забезпечує одночасну локальну присутність протеолітичного ферменту та носія, здатного зв'язувати інгібітори, що вивільняються, ферменту й стимуляторів синтезу колагену (іони заліза, мідь, гепарин й ін.). Завдяки вказаним властивостям лонгідаза володіє не лише здатністю деполімеризувати матрикс сполучної тканини у фіброзно-гранулематозних утвореннях, але й пригнічувати зворотну регуляторну реакцію, спрямовану на синтез компонентів сполучної тканини.
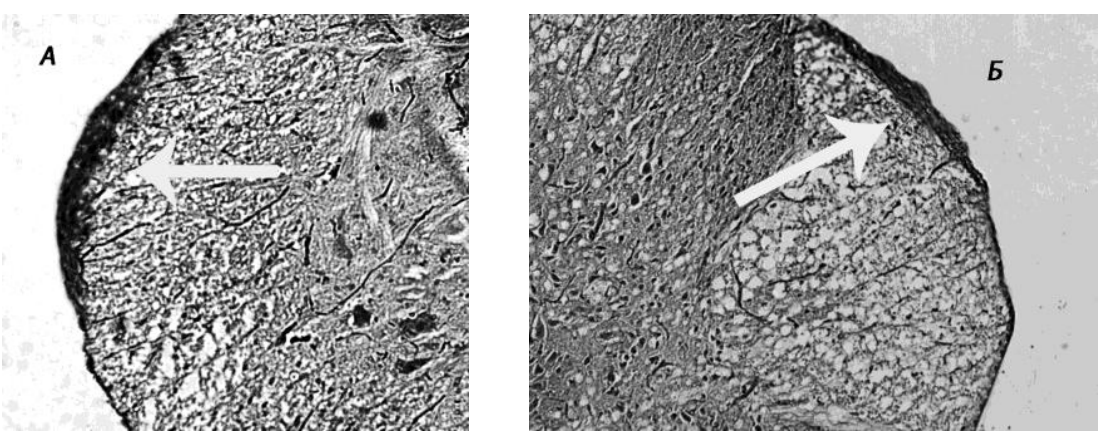

Рис. 5. Поперечний переріз спинного мозку щура при введені препарату лонгідази в концентрації 1 мл/кг, (а) 5 та (б) 10 діб після активації фіброзу (світлова мікроскопія, х100)

Стрілками показано місця виникнення фіброзних структур.

Специфічним субстратом тестикулярної гіалуронідази є глікозаміноглікани (гіалуронова кислота, хондроїтін, хондроїтін-4-сульфат, хондроїтін-6-сульфат), складові частини основи матриксу сполучної тканини. У результаті деполімеризації (розриву зв'язку між С1 ацетілглюкозаміна й С4 глюкуронової або індуронової кислот) під впливом гіалуронідази глікозаміноглікани втрачають свої основні властивості: в'язкість, здатність зв'язувати воду, іони металів, важкоформування колагенових білків у волокна, підвищується проникність тканинних бар'єрів, полегшується рух рідини в міжклітинному просторі, покращується еластичність сполучної тканини, що виявляється в зменшенні набряклості тканини, сплощенні рубців, збільшенні об'єму руху суглобів, зменшенні контрактур і запобіганні їх формуванню, зменшенні спаєчного процесу.

При лікуванні патологічного зростання сполучної тканини на сьогодні простежуємо низку нерозв'язаних проблем. Потрібний препарат, який спроможний ефективно впливати на всі ланки патологічного процесу, починаючи від стадії дії на організм ушкоджувального чинника й закінчуючи стадією розвиненого продуктивного запалення (спайки, що сформувалися, фіброз, інтерстиціальний склероз і т. ін.). Важно розв'язати проблему реактогенності препарату. Гіалуронідаза має суттєву протифіброзну дію, але цей білок при введенні природно викликає алергічну реакцію й у зв'язку 3 цим проти дії гіалуронідази спрямовано безліч ферментів, руйнівних та інактивуючих іiі. Крім того, гіалуронідаза інактивується при підвищенні температури. А у вогнищі запалення температура зазвичай підвищена. Самовведення білка неминуче викликає реакцію організму й місцеве підвищення температури, що теж інактівує гіалуронідазу. Запалення, що завершується гіперплазією сполучної тканини, завжди протікає на тлі порушення функції імунної системи - ослаблення або гіперактивності імунної відповіді. Оскільки в кожному конкретному випадку складно визначити вектор порушення імунної відповіді, потрібний препарат, який би міг протистояти патологічному зростанню сполучної тканини як у разі ослаблення, так і в разі гіперактивності імунної системи.

Висновки й перспективи подальших досліджень. Отже, наші результати показали, що лонгідаза може понизити епідуральну рубцеву адгезію в піддослідних щурів та чинить позитивну дію для на запобігання епідуральному фіброзу й зменшенню щільності фіброзної тканини. Ефективність цього препарату також потрібно перевірити в подальших експериментальних і клінічних дослідженнях. 


\section{Джерела та література}

1. Исаева Н. В. Основные подходы к лечению и профилактике послеоперационного эпидурального фиброза у больных с поясничным остеоходрозом позвоночника / Н. В. Исаева, М. Г. Дралюк // Нейрохирургия. - 2010. -№ 3. - С. 74-79.

2. Riordan J. R. Identification of the cystic fibrosis gene: cloning and characterization of complementary DNA / J. R. Riordan, J. M. Rommens, B. Kerem [et al.] // Science. - 1989. - Vol. 245. - P. 1066-1073.

3. Gabbiani G. The myofibroblast in wound healing and fibrocontractive diseases / G. Gabbiani // J. Pathol. 2003. - P. 500-503.

4. Eckes B. Fibroblast-matrix interactions in wound healing and fibrosis / B. Eckes, P. Zigrino, D. Kessler // Matrix Biol. - 2000. - Vol. 19. - P. 325-332.

5. Шуваева О. Б. Клинический полиморфизм рецидивирующих болевых синдромов после оперативного вмешательства при компрессионной радикулопатии на пояснично-крестцовом уровне / О. Б. Шуваева // Журнал неврологии и психиатрии. - 2005. - № 11. - С. 11-15.

6. Ross J. S. The postoperative lumbar spine: evaluation of epidural scar over a 1-year period / J. S. Ross, N. Obuchowski, R. Zepp // AJNR Am J Neuroradiol. - 1998. - № 19. - P. 183-186.

7. Leena James. Management of Oral Submucous Fibrosis with Injection of Hyaluronidase and Dexamethasone in Grade III Oral Submucous Fibrosis: A Retrospective Study / James Leena, Shetty Akshay, Rishi Diljith, Abraham Marin // J Int Oral Health. - 2015. - № 7. - P. 82-85.

8. Баринов А. Н. Лечение невропатической боли / А. Н. Баринов, Н. Н. Яхно // РМЖ. Т. - 2003. - 11. № 25. - C. 1419-1422.

9. Герасимова М. М. Цитомедины в комплексной терапии пояснично-крестцовых радикулопатий / М. М. Герасимова. - СПб. : Наука. 2005. - С. 114-122.

10. Жулев Н. М. Остеохондроз позвоночника / Н. М. Жулев, Ю. Д. Бадзгарадзе, С. Н. Жулев. - СПб. : Лань, 2001. - 592 c.

11. Dyakonova V. A. Study of interaction between the polyoxidonium immunomodulator and the human immune system cells / V. A. Dyakonova, V. A. Dambaeva, S. V. Dambaeva, R. M. Khaitov // Int. Immunopharmacol. 2004. - Vol. 15. - № 13. - P. 1615-1623.

12. Коржевский Д. Э. Краткое изложение основ гистологической техники для врачей и лаборантовгистологов / Д. Э. Коржевский. - СПб., 2005. - 47 с.

Фищенко Яков, Заводовский Данило, Мотузюк Александр, Матвиенко Татьяна, Ноздренко Дмитрий, Мельничук Виктория, Дубник Ольга. Влияние лонгидазы на индуцированный эпидуральный фиброз спинного мозга крыс. Исследуется влияния лонгидазы в дозе 1мл/кг на индуцированный эпидуральный фиброз спинного мозга крысы. Показано снижение количества фиброзных структур при применении препарата. При этом соотношение количества нервной ткани к соединительной в разные периоды после инициации фиброза уменьшилось на $23 \%$ после пяти суток эксперимента и 38 \% после 10. Уменьшение максимальной толщины фиброза составило 31 и 43 \% ссоответственно. Самые существенные изменения проявились в уменьшении общей площади фиброзного образования - на 46 \% после пяти суток эксперимента и 68 \% после 10. Результаты показали, что лонгидаза может снизить эпидуральную рубцовую адгезию в подопытных крысах и оказывает позитивное влияние на предотвращение эпидурального фиброза и уменьшение плотности фиброзной ткани.

Ключевые слова: фиброз, соединительная ткань, лонгидаза.

Fishcnenko Yakiv, Zavodovskyi Danylo, Motuziuk Oleksandr, Matvienko Tetayna, Nozdrenko Dmytro, Melnichyk Viktoriya, Dybnik Olena. Longidaza Impact on Artificially Induced Spinal Cord Epidural Fibrosis in Rat. Longidaza at dose $1 \mathrm{ml} / \mathrm{kg}$ impact on artificially induced epidural fibrosis in spinal cord of the wistar rat was investigated. It was shown that administration of chosen concentration of a drug leads to fibrosis structures quantity decrease. Wherein proportion between neural and connective tissue after induction of fibrosis and drug application reduced on $23 \%$ during 5 days and $38 \%$ after 10 days. Maximum fibrosis thickness decline accordingly on $31 \%$ and $43 \%$. The most significant changes was in decrease of the fibrosis area, up to $56 \%$ after 5 days of the experiment and 78 after 10 days. Results show that longidaza is effectively influences measure of pathological alteration of spinal cord tissues during epidural fibrosis. Due to longidaza administration not only pathologicaly affected area is diminish but also scar tissue itself became less dense and thick. Because of the destructiveness of used fibrosis induction methods in experiment we can suggest that probably it is possible almostly prevent fibrosis using longidaza during minor traumas of spinal cord and surrounding tissues.

Key words: fibrosis, соеденительная fabric, longidaza 